\title{
Uranium Removal from Groundwater by Permeable Reactive Barrier with Zero-Valent Iron and Organic Carbon Mixtures: Laboratory and Field Studies
}

\author{
Borys Kornilovych ${ }^{1, *}$, Mike Wireman ${ }^{2}$, Stefano Ubaldini ${ }^{3}$, Daniela Guglietta ${ }^{3}$, Yuriy Koshik ${ }^{4}$, \\ Brian Caruso ${ }^{5}$ and Iryna Kovalchuk ${ }^{6}$ \\ 1 National Technical University of Ukraine "Igor Sikorsky Kyiv Polytechnic Institute", 37 Peremogy Av., \\ 03056 Kyiv, Ukraine \\ 2 US Environmental Protection Agency-Granite Ridge Groundwater, Boulder, CO 80305, USA; \\ graniteridgegw@q.com \\ 3 Istituto di Geologia Ambientale e Geoingegneria, CNR, Area della Ricerca di Roma RM 1-Montelibretti-Via \\ Salaria Km 29,300—Monterotondo Stazione, 00015 Roma, Italy; stefano.ubaldini@igag.cnr.it (S.U); \\ daniela.guglietta@igag.cnr.it (D.G.) \\ 4 Ukrainian Scientific Research and Design Institute for Industrial Technology, Ministry of Energy and Coal \\ Industry of Ukraine, 37 Petrovsky Str., 52220 Zhovty Vody, Dnipropetrovsk Region, Ukraine; \\ ipt@iptzw.org.ua \\ 5 US Environmental Protection Agency: Currently US Fish and Wildlife Service, Department of the Interior, \\ 134 Union Blvd, Lakewood, CO 80228, USA; brian_caruso@fws.gov \\ 6 Institute for Sorption and Problems of Endoecology, National Academy of Science of Ukraine, \\ 13 General Naumov Str., 03164 Kyiv, Ukraine; kowalchukiryna@gmail.com \\ * Correspondence: b.kornilovych@gmail.com; Tel.: +38-050-840-7970
}

Received: 31 March 2018; Accepted: 24 May 2018; Published: 1 June 2018

\begin{abstract}
Zhovty Vody city, located in south-central Ukraine, has long been an important center for the Ukrainian uranium and iron industries. Uranium and iron mining and processing activities during the Cold War resulted in poorly managed sources of radionuclides and heavy metals. Widespread groundwater and surface water contamination has occurred, which creates a significant risk to drinking water supplies. Hydrogeologic and geochemical conditions near large uranium mine tailings storage facility (TSF) were characterized to provide data to locate, design and install a permeable reactive barrier (PRB) to treat groundwater contaminated by leachate infiltrating from the TSF. The effectiveness of three different permeable reactive materials was investigated: zero-valent iron (ZVI) for reduction, sorption, and precipitation of redox-sensitive oxyanions; phosphate material to transform dissolved metals to less soluble phases; and organic carbon substrates to promote bioremediation processes. Batch and column experiments with Zhovty Vody site groundwater were conducted to evaluate reactivity of the materials. Reaction rates, residence time and comparison with site-specific clean-up standards were determined. Results of the study demonstrate the effectiveness of the use of the PRB for ground water protection near uranium mine TSF. The greatest decrease was obtained using ZVI-based reactive media and the combined media of ZVI/phosphate/organic carbon combinations.
\end{abstract}

Keywords: uranium; contaminated groundwater; permeable reactive barrier; zero-valent iron

\section{Introduction}

The uranium industry is critically important for the Ukrainian economy: nearly $45 \%$ of all electric power is produced by nuclear power stations. Ukraine produces more uranium than any other European country and in 2016 was the 10th largest producer in the world: production of uranium 
from mines in Ukraine was $1006 \mathrm{t}$ /year [1]. The largest uranium deposits occur in Kryvyi Rig basin located in the western part of Dnipropetrovsk Oblast (Figure 1) and are typically associated with iron ore deposits.

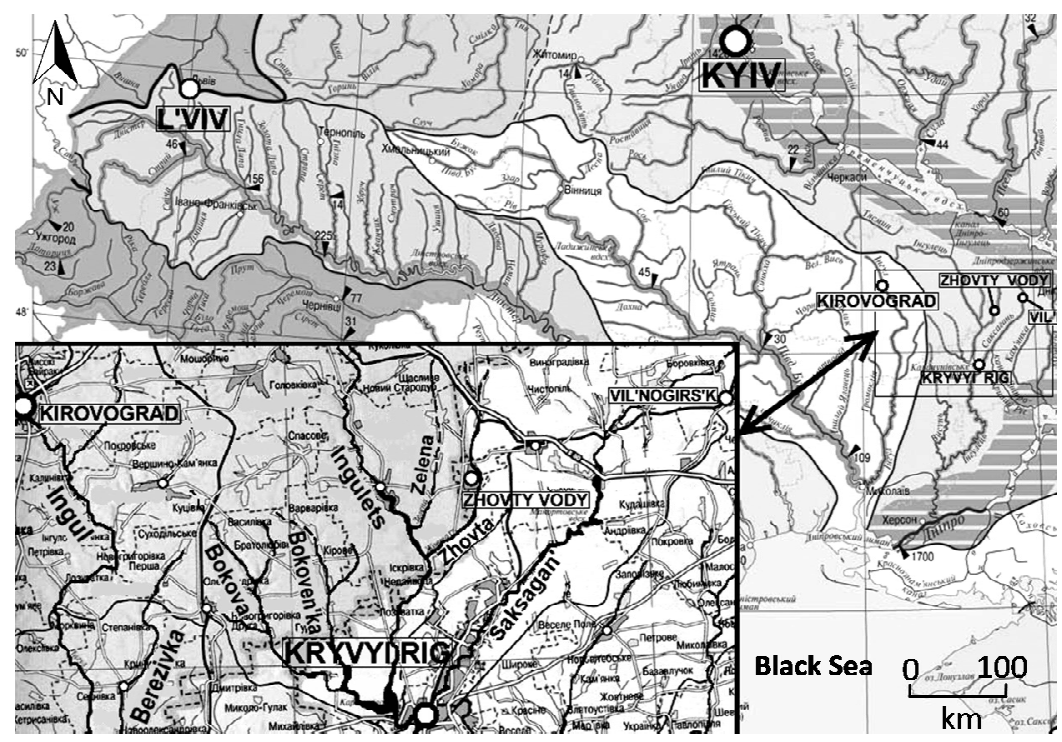

Figure 1. Kryvyi Rig Basin location.

Significant environmental pollution in the Kryvyi Rig basin relates to industrial activity in Zhovty Vody city. The largest is the state enterprise for uranium ore mining and milling- "Eastern Mining and Concentration Combine Works" (SE "VostGOK"). Waste products associated with uranium processing represent a major source of surface and groundwater contamination [2,3].

Throughout the United States and Western Europe numerous methods have been utilized for remediating water, soil and sediments contaminated with hazardous substances. A relatively new (in Eastern Europe) and potentially important in situ method is a permeable reactive barrier (PRB) constructed in the subsurface to intercept and treat contaminated groundwater which contain dissolved metals, radionuclides, and dissolved nutrients. During recent years, the use of PRBs has evolved from innovative to accepted standard practice for treatment of selected organic and inorganic contaminants. There have been more than 200 successful PRB applications all over the world, but mainly in the United States, and the US Environmental Protection Agency (EPA) designated the PRB a standard remediation technology [4-7].

The contaminant treatment zone in a PRB may be created directly using reactive materials such as iron or indirectly using materials designed to stimulate secondary physical, chemical, or biological processes. Various materials have been investigated as possible treatment materials for use in a PRB, including zeolite, hydroxyapatite, elemental iron, limestone, and others [7-11].

One of the most promising treatment materials for use in a PRB is zero-valent iron $\left(\mathrm{Fe}^{0}\right)$ which has been extensively studied in recent years [12-17]. It has been shown that iron fillings are much more effective than adsorbents in removing heavy metals and uranyl $\left(\mathrm{UO}_{2}^{2+}\right)$ from the aqueous solution. However, it is still unclear whether the removal of heavy metals and uranyl results from reductive precipitation or from adsorption onto the corrosion products of $\mathrm{Fe}^{0}$. A more exact knowledge of the chemical interactions in PRB treatment zones is needed to improve the efficiency of new designs and to predict longevity so that reliable cost assessments can be made [18-20].

It is necessary to note that in some cases of PRB applications for groundwater remediation have failed to achieve cleanup levels as predicted from bench scale tests, for molybdenum and uranium [21]. Performance failure was related to a sequence of events due to continual buildup of 
mineral precipitates on the reactive medium, loss of pore space, development of preferential flow paths, and finally complete bypass of the zero-valent iron resulting in the loss of hydraulic control.

The biological approach in PRB technology is also an innovative method that can be useful for remediating uranium contamination of water. Many environmental biotechnological applications utilize microorganisms that have key roles in the biogeochemical cycling of toxic metals and radionuclides [22-27]. Biologically induced reduction reactions can promote the attenuation of inorganic cations through direct reduction of the metal or through indirect precipitation resulting from the oxidation or reduction of an inorganic anion. Many metals, including toxic metals such as $\mathrm{Cd}, \mathrm{Cu}$, $\mathrm{Zn}, \mathrm{Mn}, \mathrm{Pb}$ are removed by this method [28-30].

In this study, special attention was devoted to uranium. It was shown that microbes had the ability to facilitate the removal of uranium from water through the sorption of $\mathrm{U}(\mathrm{VI})$ to bacterial cell walls, biological reduction of $\mathrm{U}(\mathrm{VI})$ and enzymatic production or nucleation of $\mathrm{U}$ mineral precipitates [25,31-33]. Dissolved oxygen is reduced first, followed by denitrification, followed by $\mathrm{UO}_{2} \mathrm{CO}_{3}$ reduction to uraninite and sulfate reduction to sulfide [25]. As a result, an amorphous uranium oxide may form on bacteria surfaces [34].

Biological reduction of $\mathrm{U}(\mathrm{VI})$ to insoluble $\mathrm{U}(\mathrm{IV})$ was stimulated by the addition of ethanol and trimetaphosphate to contaminated groundwater [27,35]. Also, kinetic data for microbial U(VI) reduction were obtained [36]. The process in which Citrobacter sp. produces an overabundance of alkaline phosphatase was described, which in turn causes the cell to excrete phosphate, which provides the nucleus for the precipitation of $\mathrm{U}(\mathrm{VI})$ phosphate on cell surfaces [37].

The role of inorganic support in microbiologically-induced reduction of $\mathrm{U}(\mathrm{VI})$ is very important [38]. Another very perspective approach in PRB application is to combine chemical oxidation-reduction reactions and microbiologically mediated processes [39,40].

The main objectives of this work were (1) to characterize the site at Ukrainian Uranium Center (Zhovty Vody city, Ukraine) with respect to the design and installation of a PRB to treat contaminated groundwater and (2) to study the effectiveness of different zero-valent iron and organic carbon fillings for uranium removal by PRB technology.

\section{Materials and Methods}

\subsection{Water Sampling and Analysis}

Zhovty Vody and the uranium mining district are located within the Kryvyi Rig iron-ore basin. This structurally complex basin $\left(500-600 \mathrm{~km}^{2}\right)$ occurs within the central part of the Ukrainian Shield and is underlain by Precambrian volcanic, granitic, and meta-sedimentary rocks overlain by thin, unevenly distributed Cenozoic sedimentary rocks. A variety of Quaternary alluvial, eolian and lacustrine deposits form the surface over most of the basin. The uranium deposits occur in hydrothermally altered rocks, are associated with the iron deposits, and have strata-like and lens-like forms. The deposits are typically 1-15 m thick, tens to hundreds of meters long and occur at depths up to $1.5 \mathrm{~km}$.

Since 1950s, SE "VostGOK" performed uranium ore underground mining and processing by hydrometallurgical method. Currently, hydrometallurgical plant processes ores being delivered from Ukrainian uranium deposits and produces natural uranium concentrate (uranous-uranic oxide $-\mathrm{U}_{3} \mathrm{O}_{8}$ ). The technological process is based on leaching of the uranium from ore by sulfuric acid and sorption on anionic resins (so called "resin in pulp process"). Also, underground leaching and block leaching were used.

Numerous waste disposal facilities related to uranium mining and processing have been constructed near Zhovty Vody. Liquid and solid process wastes (disposal sludge, waste water from uranium ore processing and decontamination of process equipment, etc.) are discharged through slurry pipelines into tailings storage facilities. The tailings storage facility (TSF) "Shcherbakovskoyeh" ("Shch") (Figure 2) is located about $1.5 \mathrm{~km}$ south of Zhovty Vody in the Shcherbakovskaya gully which 
is a right tributary of the Zhovta River. For many years leachate from this facility has infiltrated into the sub-surface, contaminating the underlying groundwater.

Shcherbakovskaya gully and the Shch TSF are underlain by loams, clays, and sands of primarily Quaternary age. These surficial deposits overlie highly weathered Precambrian granite with a thick residual layer at the top which functions as an aquifer. Between the Shch TSF and the Zhovta River ( $1.0 \mathrm{~km}$ to the east) all but $4-5 \mathrm{~m}$ of the Quaternary sediments have been eroded. The highly weathered granite is quite permeable and has a significant saturated thickness. Groundwater in the granite flows eastward from the area of the Shch facility and discharges to the recent alluvial sediments along the Zhovta River and directly to the Zhovta River. The gradient on the water table ranges from 0.023-0.4 The Zhovta River flows southward and discharges to the Ingulets River south of the Zhovty Vody. The Ingulets River discharges to the Black Sea.

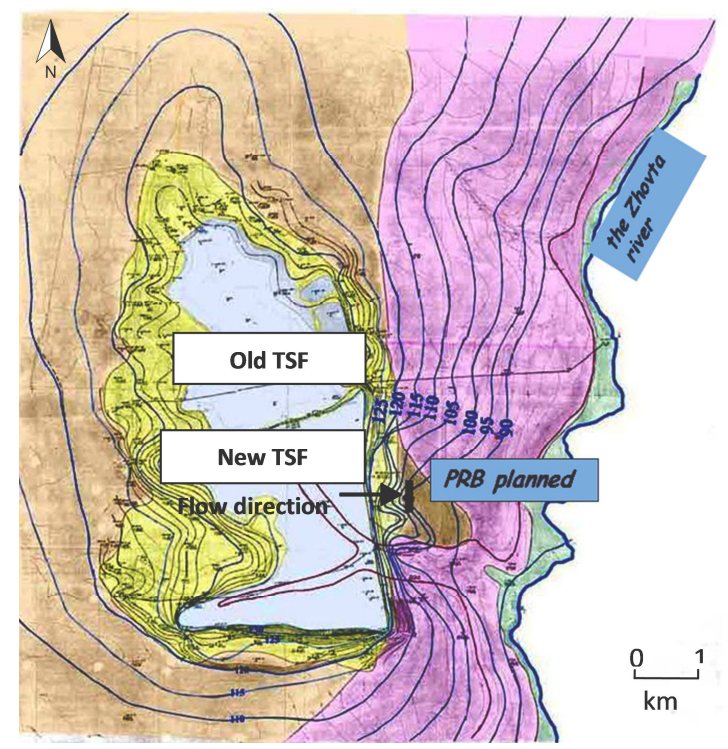

Figure 2. Hydrogeological map of the tailings storage facility site with hydroisohypses of the aquifer.

Currently, the TSF consists of two sections: an old tailings storage facility located in the northern branch of the Shcherbakovskaya gully and a new tailings storage facility located in the western branch of the gully (Figure 2). The old TSF was constructed by building a dam across the northern branch of the gully and is $1.8 \mathrm{~km}$ long, $0.9 \mathrm{~km}$ wide, and 98.4 ha in area. Its storage volume is about $5.4 \times 10^{6} \mathrm{~m}^{3}$. It was operated from 1959 to 1979 and is currently used as a standby facility. The new TSF, in operation since 1979, has an area of $151.8 \mathrm{ha}$, and a projected volume of $25.84 \times 10^{6} \mathrm{~m}^{3}$. Solid and liquid process wastes from the hydrometallurgical plant include pulp from uranium leaching, waste water from washing and decontamination of process equipment etc. Sludge drainage and industrial sewage from the neutralization station from the sulfuric acid plant are also discharged through slurry pipelines into the tailings storage facility. The waste is emplaced under the layer of water to prevent its drying and dusting.

The chemistry of the groundwater in the weathered granite aquifer has been highly contaminated by leachate infiltrating from the Shch TSF. Data from sampling near the facility indicate a groundwater contamination plume defined by a high concentration halo of nitrate and sulfate. The configuration of the plume corresponds well with the direction of groundwater flow. Dissolved solids concentrations in groundwater to the west (upgradient) of the tailings storage facility ranged from 1.0 to $1.95 \mathrm{~g} / \mathrm{L}$. Downgradient of the tailings facility the dissolved solids concentrations ranged from 2.12 to $5.33 \mathrm{~g} / \mathrm{L}$. Groundwater is mainly a sulfate, magnesium-sodium type. The $\mathrm{pH}$ ranged from 6.8 to 8.0 and the total hardness ranged from 12.04 to $86.97 \mathrm{mg}$-equiv/L. 
These data, obtained from a network of the monitoring wells installed by the enterprise SE "VostGOK", clearly indicate the presence of leachate from the tailings storage facility in the groundwater. Groundwater near the TSF was sampled from 8 monitoring holes to determine chemical and radiochemical (radionuclides of uranium series) composition. Detailed geochemical sampling was conducted in December of 2011, as well as March, May, August, November 2012 and April, June 2013. Sampling procedure was consistent with international standards, such as established by the International Organization for Standardization and the US Environmental Protection Agency [41,42].

Position of the groundwater levels was measured in all monitoring holes characterizing efficiency of the permeable reactive barrier using hydrogeological roulette with periodicity 2 times a month. Groundwater was collected using a sinking pump. Water samples were collected in disposable $0.06 \mathrm{~L}$ syringes and filtered through $0.45 \mu \mathrm{m}$ cellulose acetate filter. Ultrapure concentrated $\mathrm{HNO}_{3}$ was added $(\mathrm{pH}<2)$ to preserve the cation sample. All samples were analyzed at three different chemistry and radiochemistry laboratories: at National Technical University of Ukraine (Kyiv), Ukrainian Research-Development and Design-Prospecting Institute of Industrial Technology (Zhovty Vody) and East Mine Dressing Combine (Zhovty Vody). The concentration of metal ions $\left(\mathrm{Na}^{+}, \mathrm{K}^{+}, \mathrm{Ni}^{2+}\right.$, $\left.\mathrm{Cu}^{2+}, \mathrm{Zn}^{2+}, \mathrm{Pb}^{2+}, \mathrm{Cd}^{2+}, \mathrm{Fe}_{\text {tot }}, \mathrm{Co}_{\text {tot }}, \mathrm{Mn}_{\text {tot }}\right)$ was determined by atomic absorption spectroscopy (AAS) with AA-6300 Shimadzu. Other chemical constituents $\left(\mathrm{Mg}^{2+}, \mathrm{Ca}^{2+}, \mathrm{NH}_{4}^{+}, \mathrm{HCO}_{3}^{-}, \mathrm{Cl}^{-}, \mathrm{SO}_{4}^{2-}, \mathrm{NO}_{3}^{-}\right.$, total dissolved solids (TDS)) were determined by standard chemical procedures [43]. Dissolved uranium (in this and next sections) was quantified spectrophotometrically on UNICO 2100 UV using the Arsenazo III (1,8-dihydroxynaphthalene 3,6-disulphonic acid-2,7-bisSTA(azo-2)-phenylarsonic acid) reagent. The chemical composition of this groundwater is shown in Table 1.

Table 1. Chemical composition of contaminated groundwater from locations near planned PRB (mg/L, $\mathrm{pH} 7.2)$.

\begin{tabular}{ccccccccc}
\hline $\mathbf{C a}^{2+}$ & $\mathbf{M g}^{2+}$ & $\mathbf{N a}^{+}+\mathbf{K}^{+}$ & $\mathbf{N H}_{4}^{+}$ & $\mathbf{H C O}_{3}^{-}$ & $\mathbf{C l}^{-}$ & $\mathbf{S O}_{4}^{2-}$ & $\mathbf{N O}_{3}^{-}$ & $\mathbf{T D S}^{-}$ \\
\hline 576 & 209 & 391 & 0.92 & 448 & 182 & 2832 & 125 & 4007 \\
\hline $\mathbf{U}_{\text {sum }}$ & $\mathbf{N i}^{2+}$ & $\mathbf{C u}^{2+}$ & $\mathbf{C o}^{2+}$ & $\mathbf{M n}_{\text {sum }}$ & $\mathbf{Z n}^{2+}$ & $\mathbf{P b}^{2+}$ & $\mathbf{C d}^{2+}$ & $\mathbf{F e}_{\text {sum }}$ \\
\hline 0.42 & $<0.05$ & $<0.03$ & $<0.06$ & 0.10 & $<0.01$ & $<0.19$ & $<0.01$ & 0.05 \\
\hline
\end{tabular}

The data indicate that the concentrations of uranium, $\mathrm{SO}_{4}^{2-}$, and total dissolved solids (TDS) significantly exceed international standards. The maximum contaminant levels established by the US Environmental Protection Agency are: $0.03 \mathrm{mg} / \mathrm{L}$ for uranium, $250 \mathrm{mg} / \mathrm{L}$ for $\mathrm{SO}_{4}^{2-}$ and $500 \mathrm{mg} / \mathrm{L} \mathrm{for}$ TDS [44].

\subsection{Experimental System}

Two main approaches were applied in laboratory experiments with PRB treatment media: chemical and microbiological. The chemical tests can be performed under no flow conditions (batch tests) or under gravitational or imposed flow conditions (column tests).

The first step in the chemical approach was conducting batch tests to aid in the preliminary selection of possible reagents and to help characterize the effect of contaminated groundwater (constituents) on the reactivity of $\mathrm{Fe}^{0}$.

For this purpose, batch experiments were conducted with three different types of iron materials (all from Ukrainian Plants). The first one, zero-valent iron material 1 (sample: ZVI1) was a direct reduced iron $(\mathrm{Fe}>99.5 \%$ ) with particle size $<0.16 \mathrm{~mm}$. The second one (sample: ZVI2) was iron material $(\mathrm{Fe}>99.0 \%$ ) with particle sizes as follows: $>1.0 \mathrm{~mm}-0.4 \% ; 1.0-0.63 \mathrm{~mm}$ $-21.7 \%$; $0.63-0.4 \mathrm{~mm}-16.9 \% ; 0.4-0.31 \mathrm{~mm}-10.5 \% ; 0.31-0.2 \mathrm{~mm}-19.9 \% ; 0.2-0.16 \mathrm{~mm}-13.9 \%$; $0.16-0.1 \mathrm{~mm}-11.6 \% ; 0.1-0.063 \mathrm{~mm}-1.8 \% ; 0.063-0.05 \mathrm{~mm}-1.0 \% ;<0.05 \mathrm{~mm}-2.3 \%$. The third material (sample: ZVI3) was scrap iron (C-3.3\%; $\mathrm{Si}-2.0 \%$; Mn-0.8\%) with particle sizes between 1.0 and $2.0 \mathrm{~mm}$. 
These experiments consisted of placing a known mass of the Fe-powder in glass (or non-reactive) flasks, filling them with the contaminant solution and shaking at various times. At selected times samples of solutions from all flasks were collected and analyzed to determine uranium concentration changes and obtain physical-chemical parameters (e.g., $\mathrm{pH}$, electric conductivity, etc.).

The soluble part of humic substances, fulvic acid (FA), and $\mathrm{Na}_{2} \mathrm{CO}_{3}$ were used in the experiments to determine removal efficiency of iron materials for uranium solutions that contain complexing agents. These substances are common constituents in ground water and readily form complexes with $\mathrm{U}(\mathrm{VI})$ ions $[45,46]$. FA was extracted from lake sediments near Kyiv (Ukraine) according to literature method [43]. Ethylenediaminetetraacetic acid (EDTA), nitrilotriacetic acid (NTA) and ethylenediamineacetic acid (EDA), which are common constituents in washing solutions [47], were also used. ZVI2 as zero-valent iron material was used in these experiments.

The second step in the chemical approach was a column test which was most important for designing the PRB. The test included percolation of a solution, with a known concentration of contaminant, through a cylindrical column filled with reagent material. Because all experiments were conducted using groundwater samples with very low concentration of dissolved oxygen, some precautions were taken to prevent contact of the solutions with air.

In the microbiological approach the same laboratory experimental material was used for testing PRB design and effectiveness. Iron, sand, gravel, bone meal and sawdust, which widely used as fillings for biological PRB [4,5], were selected for testing. An activator was also added to initiate bioreduction processes. It contained anaerobic bacterial communities with uranium-removal bacteria which were prepared from a previously cultivated mixed indigenous culture of bacteria from bottom sediments of Zhovta River near mine tailings storage. Yeast decoction and cysteine were added to the solution for biostimulation.

Various mixtures of materials were tested for further application as an active PRB treatment medium (detailed composition of the medium is in Section 2.3):

1. Powdered ZVI + sand (inorganic active filling);

2. Powdered ZVI + gravel + bone meal + sawdust + activator (organic-inorganic active filling);

3. Gravel + bone meal + sawdust + activator (organic active filling).

A sketch of the apparatus, which was designed and commissioned for testing PRB treatment media, is shown in Figure 3.

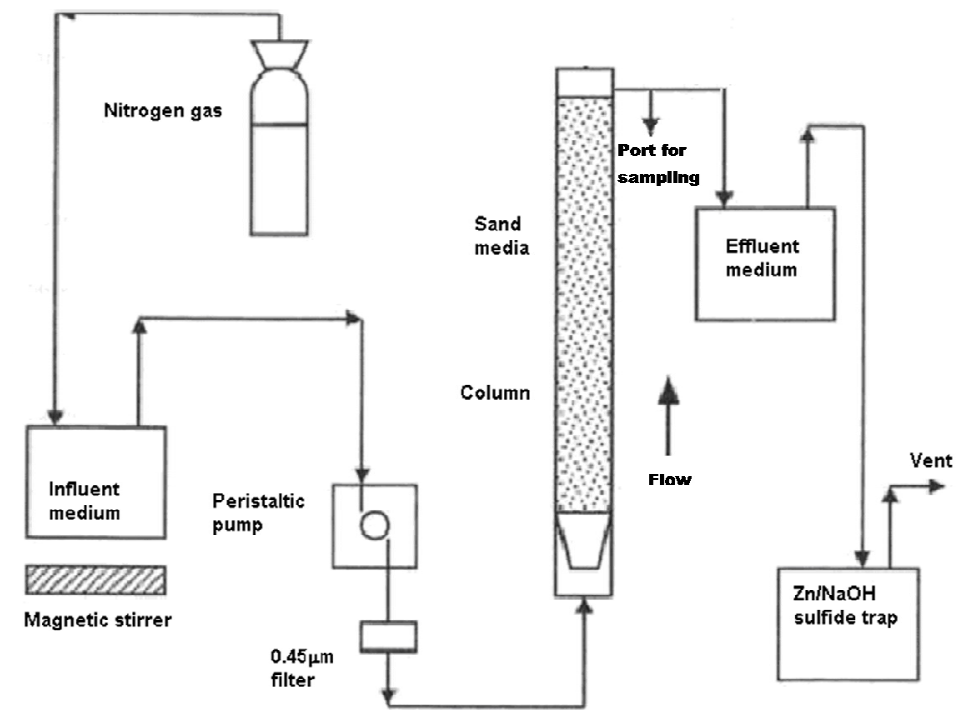

Figure 3. A schematic diagram of the up flow anaerobic packed bed reactor setup. 
A packed bed system was constructed from Plexiglas with an overall height of $30 \mathrm{~cm}$, internal diameter of $8 \mathrm{~cm}$ and a net empty working volume of $1 \mathrm{~L}$. It was equipped with an $0.8 \mathrm{~cm}$ diameter port used for sampling liquid located $20 \mathrm{~cm}$ from the bottom. The flow was dispersed with the aid of a frustum shaped cowling located at the base of the column, which also served to contain the porous media.

The influent was pumped from the reservoir tank to the inlet of the reactor by means of a pre-calibrated variable speed peristaltic pump at a flow rate of $0.006-0.15 \mathrm{~L} / \mathrm{h}$ (approximately $0.5-10$ pore volumes per day). Inert gas $\left(\mathrm{N}_{2}\right.$ or $\left.\mathrm{CO}_{2}\right)$ is continuously purged through the influent reservoir to lower the oxygen content of the influent solution and satisfy the anaerobic conditions during column experiments. A series of preliminary experiments were conducted to determine the operability of column apparatus. For these preliminary experiments inorganic materials were used as PRB active treatment medium. The stability of the equipment was demonstrated for all preliminary tests.

The effluent volume was recorded daily by weighing the mass of water collected, allowing the average flow rate during the collection period to be calculated. Columns were operated in different experimental series, but the total treated pore volumes for the individual columns differed during equal periods of time because of differences in the voidage.

\subsection{Chemical and Microbial Tests}

In the first series of column experiments sieved sand (particle size $0.6-2 \mathrm{~mm}$ ) and iron material (ZVI2) were used. The ratio of the components in reactive media was $1: 10$ ( $\mathrm{Fe}^{0}$ powder to sand). After filling with the reactive mixtures, the columns were purged with several pore volumes of deoxygenated water to ensure complete removal of air (oxygen) prior to addition of the test solution.

The total duration of each series of experiments was $\sim 90$ days. The samples of purified water after columns were collected and analyzed with the use of special port for sampling every day during first month of the set and every 2-3 days during next two months. Calculation of the removed uranium was based on the difference between the influent and effluent concentrations. After the end of the experiment the leaching procedure was provided for determination of the uranium distribution in reactive media in the column. The whole reactive material from every column was divided into layers $(1 \mathrm{~cm})$ and then treated with $\mathrm{HNO}_{3}$. The concentration of uranium in leaching solution from each layer was determined and then the total content was calculated. Also, it was interesting to determine the distribution of released uranium within the separate layers of the reactive media. The samples were taken at different points of separate reactive media layers and then analyzed.

An organic-inorganic mixture was used in a second series of anaerobic bioremediation experiments with an indigenous consortium of microorganisms from mine water. An organic component consisting of sewage sludge, bone meal, sawdust and activator was used with an inorganic component consisting of gravel and $\mathrm{Fe}^{0}$ (ZVI2). All materials (except ZVI2 which was taking from enterprise "Public Plant of Powder Metallurgy", Brovary city, Ukraine) were obtained from local enterprises in Zhovty Vody. A mixed indigenous culture of bacteria as one of the components of the activator was also added to this composition. The ratio of $\mathrm{Fe}^{0}$ powder, sewage sludge, bone meal, sawdust, water (with activator) and gravel in the mixture was chosen 0.17:1:2:3:4:17, in accordance with composition of typical reactive mixtures for biological PRBs $[4,5,48]$.

The activator was prepared using sludge samples from bottom sediments of Zhovta River near the "Sch" mine tailings storage facility. A culture of bacteria for these tests was cultivated by suspending $0.04 \mathrm{~L}$ of the sediment in $0.4 \mathrm{~L}$ of basal medium in the presence of $50 \mathrm{mg} / \mathrm{L} \mathrm{U}(\mathrm{VI})$. The propagation was continued with basal medium which was replaced weekly. Basal medium was modified from Postgate $\mathrm{C}$ medium with $4.5 \mathrm{~g} / \mathrm{L} \mathrm{Na}_{2} \mathrm{SO}_{4}$ as electron acceptor [49]. Resazurin $(1 \mathrm{mg} / \mathrm{L})$ was added as a redox indicator to show any contamination by molecular oxygen. The $\mathrm{pH}$ was adjusted to 7.5 with $50 \%$ $\mathrm{NaOH}(w / v)$. After four weeks of domestication, sulfate-reducing bacteria (SRB) for lab experiments were obtained. The activation was done periodically to maintain the activity of SRB. The columns 
were wet packed with all components. The experimental procedure was the same as in experiments with inorganic treatment medium.

In a third series of experiments only treatment medium of organic composition was used. Sewage sludge, bone meal, sawdust, water solution of activator and inert inorganic component (gravel) were mixed in the following ratio 1:2:3:4:17. A mixed indigenous culture of bacteria as one of the components of the activator was also used in this series of experiments.

Contaminated groundwater from sites near the uranium mine TSF was used in these column experiments. The concentration of uranium in influent was increased to $10 \mathrm{mg} / \mathrm{L}$ to approach the exhausting of the sorption capacity of the medium. This solution was pumped to the inlet of the column. All U(VI) reduction experiments were conducted anaerobically in the dark.

\subsection{Field Tests}

Sampling for radionuclide composition of groundwater in 8 monitoring holes in the PRB area was conducted to evaluate the efficiency of the PRB cylinders with the different types of reactive media.

Because of the significant risk the TSF poses to the Zhovta River and the favorable hydrogeological setting, the Shch tailings facility site was chosen for a PRB installation. The near surface geology at the PRB locations, as determined from numerous boreholes, is as follows:

- Diluvial soil organic layer of $0.9 \mathrm{~m}$ in thickness-the upper layer of soil;

- Black alluvial loam of $2.6 \mathrm{~m}$ in thickness—-the middle layer of soil;

- Residual soil of crystalline rocks—gruss-gravel formations of $2.5 \mathrm{~m}$ in thickness-the lower layer of soil.

The crystalline rocks of Precambrian occur from a depth of $6.0 \mathrm{~m}$. Results from our groundwater flow modeling, using VISUAL MODFLOW v. 2.8.2 (Waterloo Hydrogeologic Inc., 2000, Waterloo, ON, Canada) indicate that $93.8 \%$ of the groundwater discharge to the Zhovta River is from weathered, residual crystalline rocks.

The position of the PRB in the region of TSF is presented in Figure 2. The PRB consists of 21 cylinders installed in three clusters of boreholes (Figure 4). Each cluster of cylinders contained a different treatment media. The first cluster of boreholes (group A) contained inorganic active filling- $-\mathrm{Fe}^{0}$ powder and sand (T-1-T-7), second cluster (group B) contained organic-inorganic active filling - sewage sludge, bone meal, sawdust and water (with components of activator) and gravel (T-8-T-14) and third cluster (group C) contained organic active filling-sewage sludge, bone meal, sawdust, water solution of activator and gravel (T-15-T-21). The holes that house the treatment cylinders are $0.35 \mathrm{~m}$ in diameter. The holes in each cluster are staggered to make sure all groundwater flow is intercepted. The depth of the holes is $6 \mathrm{~m}$.
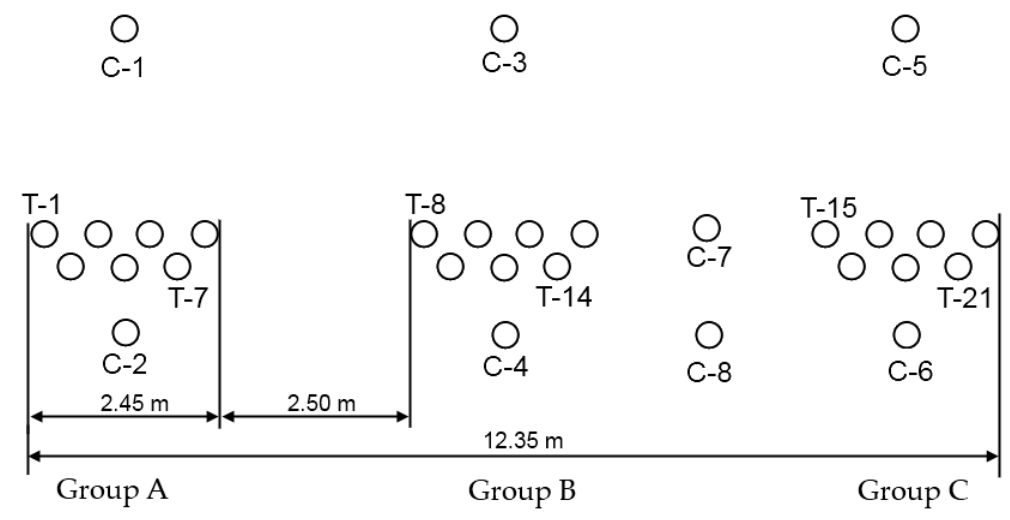

Figure 4. Scheme of PRB holes. Group A—cylinders filled with inorganic active filling; Group B-with organic-inorganic active filling; Group $\mathrm{C}$-with organic active filling. 
Sampling for radionuclide composition of groundwater in 8 monitoring holes in the PRB area (C-1-C-8) was conducted to evaluate the efficiency of PRB cylinders. Monitoring holes were installed up-gradient (holes C-1, C-3, C-5), within (C-7, C-8) and down-gradient of the PRB (C-2, C-4, C-6) (Figure 4).

\section{Results and Discussion}

\subsection{Laboratory Tests}

The results of the U(VI) removal by different types of ZVI are shown in Figure 5. The adjusted initial $\mathrm{pH}$ was 6 . The greatest uranium removal occurred using samples of ZVI1 (the most dispersed iron material). The worst results were for scrap material ZVI3 with the largest particle size [50].

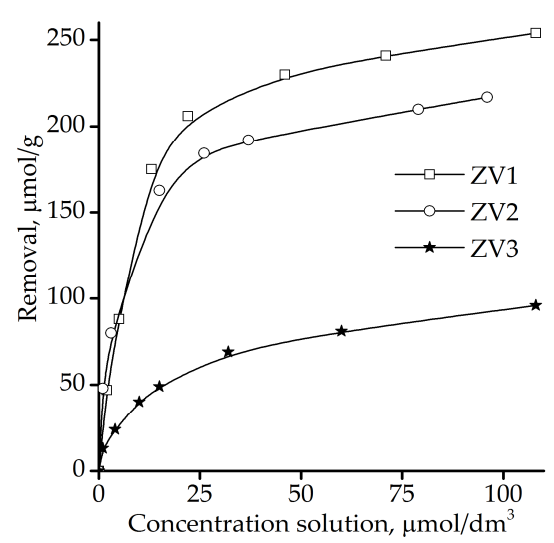

(a)

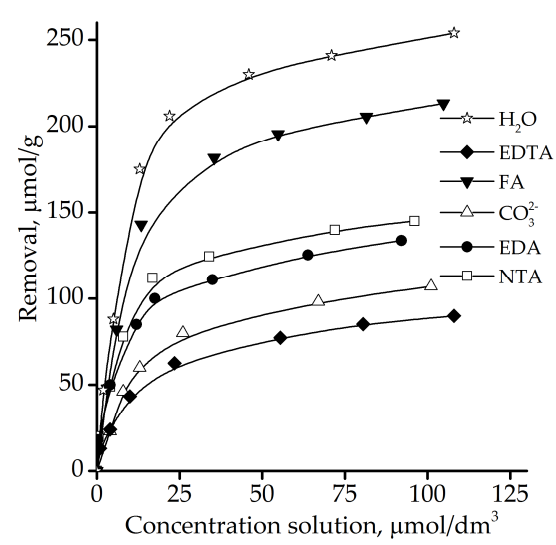

(b)

Figure 5. (a) Removal of U(VI) by different types of $\mathrm{Fe}^{0}$; (b) Effect of selected ligands (FA, EDTA, NTA, EDA, and $\mathrm{Na}_{2} \mathrm{CO}_{3}$ ) on the $\mathrm{U}(\mathrm{VI})$ removal by $\mathrm{ZVI1}$.

It was shown previously that reactivity of iron-containing materials may be considerably affected by some contaminants and groundwater constituents which demonstrate significant complexing of different metals [4,51].

Figure $5 \mathrm{~b}$ compares the results of the $\mathrm{U}(\mathrm{VI})$ fixation by $\mathrm{Fe}^{0}$ (ZVI1) for 3 days in the presence of $5 \times 10^{-4} \mathrm{M}$ EDTA, $5 \times 10^{-4} \mathrm{M} \mathrm{NTA}, 5 \times 10^{-4} \mathrm{M} \mathrm{EDA}, 10^{-3} \mathrm{M} \mathrm{Na}_{2} \mathrm{CO}_{3}$, and $100 \mathrm{mg} / \mathrm{L}$ FA solutions. These ligands readily form complexes with $\mathrm{U}(\mathrm{VI})$ ions and include the soluble part of humic substances, fulvic acid (FA), and $\mathrm{CO}_{3}^{2-}$, which are common constituents in ground water; and ethylenediaminetetraacetic acid (EDTA), nitrilotriacetic acid (NTA) and ethylenediamineacetic acid (EDA), which are common constituents in washing solutions. Uranium removal efficiency diminished with the addition of all the ligands.

This is due to the changes in uranium speciation after the addition of carbonate and other complexing agents. One of the important uranium fixation mechanisms is sorption. As shown in the speciation diagrams in [52], positively charged uranyl $\left(\mathrm{UO}_{2}^{2+}\right)$ species dominate under $\mathrm{CO}_{2}$-free conditions, while solutions in the presence of carbonate contain predominantly negatively charged $\mathrm{UO}_{2}\left(\mathrm{CO}_{3}\right)_{2}^{2-}, \mathrm{UO}_{2}\left(\mathrm{CO}_{3}\right)_{3}^{4-}$, or uncharged $\mathrm{UO}_{2} \mathrm{CO}_{3}$ complexes, with rather weak sorption properties. The same situation exists for other ligands [47,53]. Clearly, the lowest uranium removal from solution occurred with strong ligands such as EDTA and $\mathrm{CO}_{3}^{2-}$ and the highest with the weaker ligand FA.

In all the column tests almost complete U(VI) fixation occurred. Results (Figure 6a) show that practically full U(VI) removal was observed during all period of experiments (90 days).

The experiments showed that the distribution of retained uranium in the columns was not uniform-most of the uranium was concentrated in the lower layers of the reactive media near the bottom of the column (Figure 6b). Also, the specific contents of uranium at different points within 
the separate layers of the reactive media are not close by value, which indicates that the flows of the contaminated solution are not uniform in cross-section of the columns [54,55].

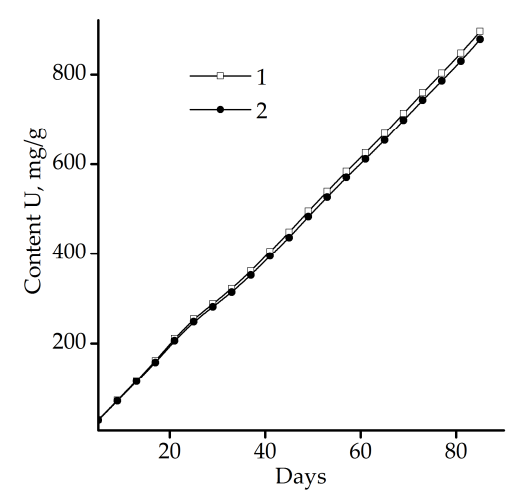

(a)

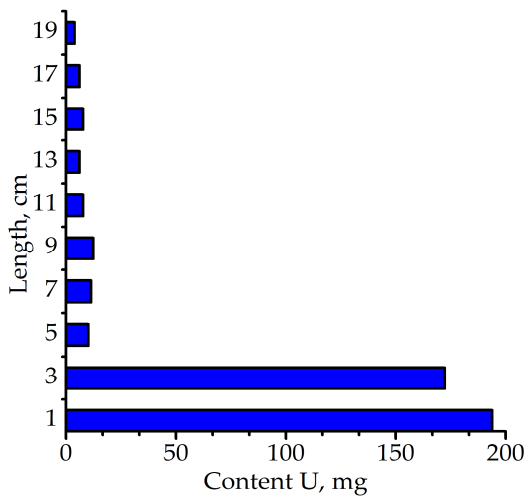

(b)

Figure 6. (a) Uranium released from contaminated water in column with ZVI2 and sand: 1-total uranium in the influent; 2 -total released uranium; (b) Distribution of uranium in the reactive media in the column.

\subsection{Field Tests}

Water table contour maps for August 2012 and June 2013 are shown in Figure 7. These maps indicate a seasonal change in the direction groundwater flow. The dominant groundwater flow in the PRB area takes place towards the Zhovta River.

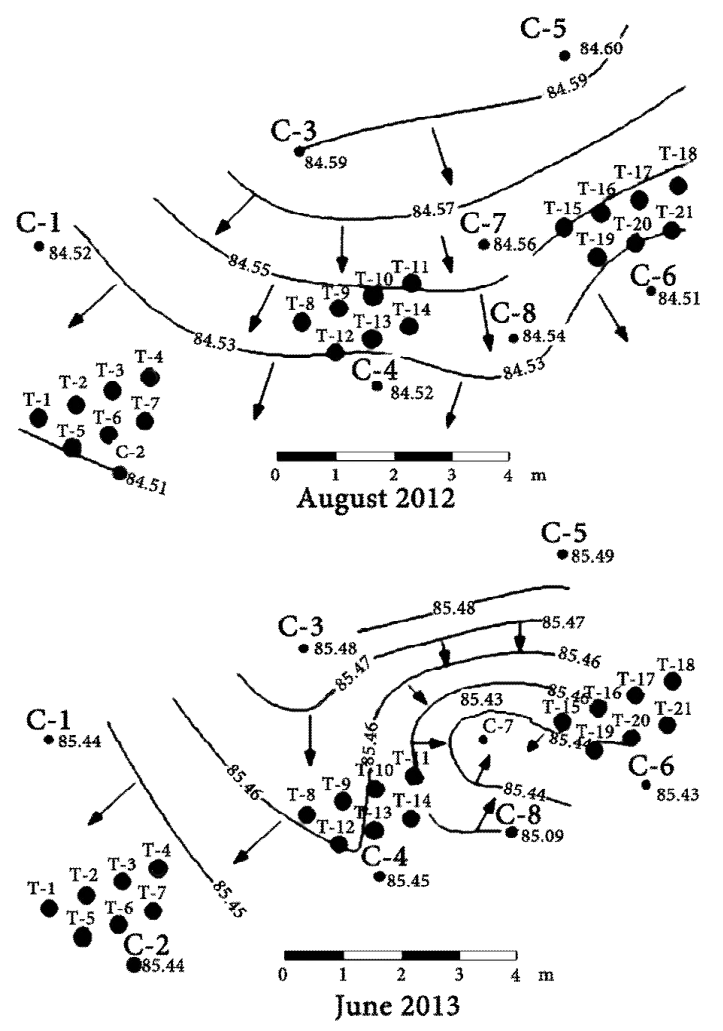

Figure 7. The change of groundwater flow direction $(\rightarrow$ ) during the period of observation.

As stated previously, all (93.8\%) groundwater flow to the Zhovta River occurs in the aquifer comprised of residual soil of crystalline rocks. 
The position of 21 PRB cylinders and 8 monitoring holes on water table contour maps is presented in Figure 7.

Results for total uranium content $\left({ }^{234} \mathrm{U},{ }^{238} \mathrm{U}\right.$ and $\left.{ }^{238} \mathrm{U}\right)$ in groundwater from 8 monitoring holes are presented in Figure 8. The comparison of the obtained results for monitoring holes which were situated in pairs, before and after different groups of PRB cylinders, clearly indicate a considerable decrease in uranium contamination of groundwater after flow through the PRB with ZVI2.

The greatest decrease was observed in monitoring holes C-1 (Figure 7) and C-2, which are located near PRB cylinders filled with inorganic filling and in monitoring holes C-3 (Figure 7) and C-4 which are located near PRB cylinders filled with organic-inorganic filling. Smaller decreases were observed after flow through cylinders with organic filling (as indicated by data from monitoring holes C-5 (Figure 7) and C-6) because of the clayey and sandy character of the soil near the uranium mine TSF and the low content of microorganisms from the indigenous mine consortium.

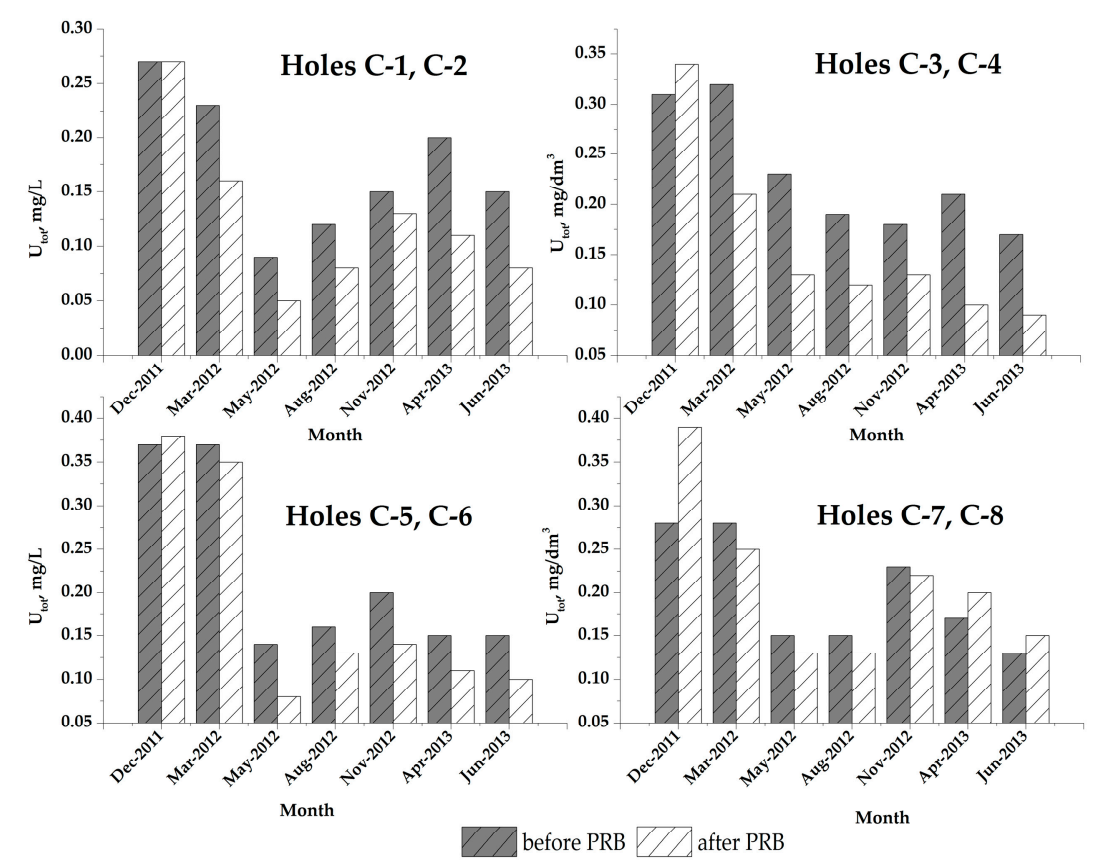

Figure 8. Uranium content in groundwater at PRB site: before PRB (monitoring hole C-1, C-3, C-5, C-7); after PRB (monitoring hole C-2, C-4, C-6, C-8) (Figure 7).

Even though groundwater flow is spatially and temporally complex at the PRB site the remedial performance of PRB is significant. The uranium content in groundwater flowing through the PRB was reduced by more than $50 \%$. Therefore, a new design for a PRB is proposed. Such PRB construction with non-continuous reactive media allows reduction of the installation costs significantly. Even for the cheapest passive remediation methods, continuous wall and funnel-and-gate PRB systems, the costs of the PRB may be high depending of the construction length and especially the depth in the ground $[4,5]$. Instead of a conventional continuous barrier or a funnel-and-gate, this novel design consists of rows of cylinders with different reactive materials. This PRB design showed high efficiency for groundwater remediation of uranium contamination in the Ukrainian region of uranium mining and processing. The obtained results proved that the use of PRB with single and double rows of cylinders with active inorganic or inorganic-organic fillings provided necessary levels of groundwater purification in the case of low or middle uranium concentration (up to $0.3-0.4 \mathrm{mg} / \mathrm{L}$ ). Three or more offset rows are needed for higher contaminant concentrations. 


\section{Conclusions}

The results of laboratory tests of the $\mathrm{U}(\mathrm{VI})$ removal by different types of ZVI show that the greatest efficiency occurred using samples of the most dispersed iron material (zero-valent iron with very fine particle size-ZVI1). Uranium removal diminished with the addition of all most significant ligands presented in ground water.

A pilot-scale PRB was installed near the uranium tailing storage facility located in Ukrainian Uranium Center (Zhovty Vody city, Ukraine). The initial concentrations of uranium, $\mathrm{SO}_{4}^{2-}$, and total dissolved solids in groundwater at that site significantly exceed international standards. A new design for a PRB is used. Instead of a conventional continuous barrier or a funnel-and-gate, this design consists of rows of cylinders with iron-reactive materials. Such PRB construction with non-continuous reactive media typically reduces allows considerable reduction of the installation costs.

After two years of monitoring a pilot-scale PRB, utilizing zero-valent iron and organic carbon treatment media, results indicate that uranium concentrations in groundwater at the PRB site were reduced from $0.38 \mathrm{mg} / \mathrm{L}$ to $0.07-0.15 \mathrm{mg} / \mathrm{L}$. The greatest decrease was obtained using a treatment media of powder zero-valent iron and sand, and a treatment media of sewage sludge, bone meal, sawdust, water (with components of activator) and gravel.

Smaller decreases were observed using pure organic carbon treatment media because of the clayey and sandy character of the soil near the uranium mine TSF and the low content of microorganisms from the indigenous mine consortium. Probably the higher content of microorganisms (as in silt or black earth soil) stipulate the increasing of the level of groundwater purification.

Even in a complex groundwater flow system at the PRB site and the mine tailing storage facility the positive effect of PRB is significant, reducing the uranium content in groundwater at PRB site by $50 \%$.

Author Contributions: Conceptualization, B.K., M.W. and B.C.; Methodology, B.K., M.W. and B.C.; Sampling and Analysis, Y.K. and D.G.; Field Tests, B.K. and Y.K.; Experiments, I.K. and D.G.; Data Analysis and Discussion, B.K., S.U. and I.K.; Writing-Original Draft Preparation, B.K., I.K. and S.U.

Funding: Funding for this research was supported by the U.S. Environmental Protection Agency, under projects P-322 "Regional evaluation of mining-related metals contamination, risks, and innovative remediation technologies in Ukraine and Georgia" and P-454 "Development of innovative environmental technology for remediation of contaminated groundwater in Ukraine" with the Science and Technology Center in Ukraine.

Conflicts of Interest: The authors declare no conflict of interest.

\section{References}

1. World Uranium Mining Production. Available online: http://www.world-nuclear.org/information-library / nuclear-fuel-cycle/mining-of-uranium/world-uranium-mining-production.aspx (accessed on 13 May 2018).

2. Kornilovych, B.; Wireman, M.; Caruso, B.; Koshik, Y.; Pavlenko, V.; Tobilko, V. The use of permeable reactive barrier against contaminated groundwater in Ukraine. Central Eur. J. Occup. Environ. Med. 2009, 15, 73-85.

3. Wireman, M.; Kornilovych, B. Installation of a permeable reactive barrier in uranium mining district-East Central Ukraine. Newsl. Int. Assoc. Hydrogeol. U.S. Natl. Chapter 2012, 41, 12-14.

4. Interstate Technology \& Regulatory Council. Permeable Reactive Barriers: Lessons Learned/New Directions. PRB-4; Interstate Technology \& Regulatory Council, Permeable Reactive Barriers Team: Washington, DC, USA, 2005. Available online: www.itrcweb.org (accessed on 31 March 2018).

5. Interstate Technology \& Regulatory Council. Permeable Reactive Barriers: Technology Update. PRB-5; Interstate Technology \& Regulatory Council, PRB; Technology Update Team: Washington, DC, USA, 2011. Available online: www.itrcweb.org (accessed on 31 March 2018).

6. Fernando, W.A.M.; Ilankoon, I.M.S.K.; Syed, T.H.; Yellishetty, M. Challenges and opportunities in the removal of sulphate ions in contaminated mine water: A review. Miner. Eng. 2018, 117, 74-90. [CrossRef]

7. Fu, F.; Dionysiou, D.D.; Liu, H. The use of zero-valent iron for groundwater remediation and wastewater treatment: A review. J. Hazard. Mater. 2014, 267, 194-205. [CrossRef] [PubMed] 
8. Waybrant, K.R.; Blowes, D.W.; Ptacek, C.J. Selection of reactive mixtures for use in permeable reactive walls for treatment of mine drainage. Environ. Sci. Technol. 1998, 32, 1972-1979. [CrossRef]

9. Gu, B.; Liang, L.; Dickey, M.J.; Yin, X.; Dai, S. Reductive precipitation of uranium (VI) by zero-valent iron. Environ. Sci. Technol. 1998, 32, 3366-3373. [CrossRef]

10. Bowman, R.S. Applications of surfactant-modified zeolites to environmental remediation. Micropor. Mesopor. Mater. 2003, 61, 43-56. [CrossRef]

11. Natale, F.D.; Natale, M.D.; Greco, R.; Lancia, A.; Laudante, C.; Musmarra, D. Groundwater protection from cadmium contamination by permeable reactive barriers. J. Hazard. Mater. 2008, 160, 428-434. [CrossRef] [PubMed]

12. Blowes, D.W.; Ptacek, C.J.; Jambor, J.L. In situ remediation of chromate contaminated groundwater using permiable reactive walls: Laboratory studies. Environ. Sci. Technol. 1997, 31, 3348-3357. [CrossRef]

13. Farrell, J.; Bostick, W.D.; Jarabek, R.J.; Fiedor, J.N. Uranium removal from ground water using zero-valent iron media. Ground Water 1999, 37, 618-624. [CrossRef]

14. Cundy, A.B.; Hopkinson, L.; Whitby, R.L.D. Use of iron-based technologies in contaminated land and groundwater remediation: A review. Sci. Total Environ. 2008, 400, 42-51. [CrossRef] [PubMed]

15. Wilkin, R.T.; Acree, S.D.; Ross, R.R.; Beak, D.G.; Lee, T.R. Performance of a zerovalent iron reactive barrier for the treatment of arsenic in groundwater: Part 1. Hydrogeochemical studies. J. Contam. Hydrol. 2009, 106, 1-14. [CrossRef] [PubMed]

16. Guo, X.; Yang, Z.; Don, H.; Guan, X.; Ren, Q.; Lv, X.; Jin, X. Simple combination of oxidants with zero-valent-iron (ZVI) achieved very rapid and highly efficient removal of heavy metals from water. Water Res. 2016, 88, 671-680. [CrossRef] [PubMed]

17. Li, S.; Wang, W.; Liang, F.; Zhang, W. Heavy metal removal using nanoscale zero-valent iron (nZVI): Theory and application. J. Hazard. Mater. 2017, 322, 163-171. [CrossRef] [PubMed]

18. Yabusaki, S.; Cantrell, K.; Sass, B.; Steefel, C. Multicomponent reactive transport in an in situ zero-valent iron cell. Environ. Sci. Technol. 2001, 35, 1493-1503. [CrossRef] [PubMed]

19. Jin, S.O.; Jeen, S.-W.; Gillham, R.W.; Gui, L. Effect of initial iron corrosion rate on long-term performance of iron permeable reactive barriers: Column experiments and numerical simulation. J. Contam. Hydrol. 2009, 103, 145-156. [CrossRef]

20. Chekli, L.; Bayatsarmadi, B.; Sekine, R.; Sarkar, B.; Maoz Shen, A.; Scheckel, K.G.; Skinner, W.; Naidu, R.; Shon, H.K.; Lombi, E.; et al. Analytical characterisation of nanoscale zero-valent iron: A methodological review. Anal. Chim. Acta 2016, 903, 13-35. [CrossRef] [PubMed]

21. Morrison, S.J.; Mushovic, P.S.; Niesen, P.L. Early breakthrough of molybdenum and uranium in a permeable reactive barrier. Environ. Sci. Technol. 2006, 40, 2018-2024. [CrossRef] [PubMed]

22. Lloyd, J.R.; Lovley, D.R. Microbial detoxication of metals and radionuclides. Curr. Opin. Biotechnol. 2001, 12, 248-253. [CrossRef]

23. Landa, E.R. Uranium mill tailings: Nuclear waste and natural laboratory for geochemical and radioecological investigations. J. Environ. Radioact. 2004, 77, 1-27. [CrossRef] [PubMed]

24. Malik, A. Metal bioremediation through growing cells. Environ. Int. 2004, 30, 261-278. [CrossRef] [PubMed]

25. Kalin, M.; Wheeler, W.N.; Meinrath, G. The removal of uranium from mining waste water using algal/microbial biomass. J. Environ. Radioact. 2005, 78, 151-177. [CrossRef] [PubMed]

26. Zagury, G.J.; Kulnieks, V.I.; Neculita, C.M. Characterization and reactivity assessment of organic substrates for sulphate-reducing bacteria in acid mine drainage treatment. Chemosphere 2006, 64, 944-954. [CrossRef] [PubMed]

27. Merroun, M.; Selenska-Pobell, S. Bacterial interactions with uranium: An environmental perspective. J. Contam. Hydrol. 2008, 102, 285-295. [CrossRef] [PubMed]

28. Benner, S.G.; Blowes, D.W.; Gould, W.D.; Gerbert, R.B.; Ptacek, C.J. Geochemistry of a permeable reactive barrier for metals and acid mine drainage. Environ. Sci. Technol. 1999, 33, 2793-2799. [CrossRef]

29. Logan, M.V.; Reardon, K.F.; Figueroa, L.A.; McLain, J.E.T.; Ahmann, D.M. Microbial community activities during establishment, performance, and decline of bench-scale passive treatment systems for mine drainage. Water Res. 2005, 39, 4537-4551. [CrossRef] [PubMed]

30. Qiu, R.; Zhao, B.; Liu, J.; Huang, X.; Li, Q.; Brewer, E.; Wang, S.; Shi, N. Sulfate reduction and copper precipitation by a Citrobacter sp. isolated from a mining area. J. Hazard. Mater. 2009, 164, 1310-1315. [CrossRef] [PubMed] 
31. Spasonova, L.N.; Tobilko, V.Y.; Leshchuk, I.A.; Gvozdyak, P.I.; Kornilovich, B.Y. Sorption of U(VI) ions on the natural association of microorganisms of activated sludge and pure culture Bacillus polymyxa IMB 8910. J. Water Chem. Technol. 2006, 28, 61-68.

32. Chabalala, S.; Chirwa, E.M.N. Removal of uranium (VI) under aerobic and anaerobic conditions using an indigenous mine consortium. Miner. Eng. 2010, 23, 526-531. [CrossRef]

33. Zhengji, Y. Microbial removal of uranyl by sulfate reducing bacteria in the presence of Fe(III) (hydr) oxides. J. Environ. Radioact. 2010, 101, 700-705. [CrossRef] [PubMed]

34. Abdelouas, A.; Nuttall, H.E.; Lutze, W.; Lu, Y. In situ removal of uranium from groundwater. In Proceedings of the International Conference on Tailings and Mine Waste'98, Fort Collins, CO, USA, 26-28 January 1998; Balkema, A.A., Ed.; Brookfield, VT: Rotterdam, The Netherlands, 1998; pp. 669-677.

35. Abdelouas, A.; Lutze, W.; Gong, W.; Nuttall, H.E.; Strietelmeier, B.A.; Travis, B.J. Biological reduction of uranium in groundwater and subsurface soil. Sci. Total Environ. 2000, 250, 21-35. [CrossRef]

36. Spear, J.R.; Figueroa, L.A.; Honeyman, B.D. Modeling reduction of uranium U(VI) under variable sulfate concentrations by sulfate-reducing bacteria. Appl. Environ. Microbiol. 2000, 66, 3711-3721. [CrossRef] [PubMed]

37. Macaskie, L.E.; Bonthrone, K.M.; Yong, P.; Goddard, D.T. Enzymically mediated bioprecipitation of uranium by a Citobacter sp.: A concerted role for exocellular lipopolysaccharide and associated phosphatase in biomineral formation. Microbiology 2000, 146, 1855-1867. [CrossRef] [PubMed]

38. Bender, J.; Duff, M.C.; Phillips, P.; Hill, M. Bioremediation and bioreduction of dissolved U(VI) by microbial mat consortium supported on silica gel particles. Environ. Sci. Technol. 2000, 34, 3235-3241. [CrossRef]

39. Sasaki, K.; Blowes, D.W.; Ptacek, C.J.; Gould, W.D. Immobilization of Se(VI) in mine drainage by permeable reactive barriers: Column performance. Appl. Geochem. 2008, 23, 1012-1022. [CrossRef]

40. Guo, Q.; Blowes, D.W. Biogeochemistry of two types of permeable reactive barriers, organic carbon and iron-bearing organic carbon for mine drainage treatment: Column experiments. J. Contam. Hydrol. 2009, 107, 128-139. [CrossRef] [PubMed]

41. ISO 5667-3:2003. Water Quality-Sampling; International Organization for Standardization: Geneva, Switzerland, 2003.

42. Surface Water Sampling. Available online: https://www.epa.gov/quality/surface-water-sampling (accessed on 20 May 2018).

43. Standard Methods for the Examination of Water and Wastewater, 22nd ed.; Bridgewater, L., Rice, E.W., Baird, R.B., Eaton, A.D., Clesceri, L.S., Eds.; APHA-AWWA-WEF: Washington, DC, USA, 2012; 1496p, ISBN 97808755301300875530133.

44. OGWDW. Available online: http:/ / www.epa.gov/OGWDW (accessed on 13 May 2018).

45. Pratopo, M.I.; Moriyama, H.; Higashi, K. Carbonate complexation of neptunium (IV) and analogous complexation of ground-water uranium. Radiochim. Acta 1990, 51, 27-31. [CrossRef]

46. Schmeide, K.; Sachs, S.; Bubner, M.; Reich, T.; Heise, K.H.; Bernhard, G. Interaction of uranium(VI) with various modified and unmodified natural and synthetic humic substances studied by EXAFS and FTIR spectroscopy. Inorg. Chim. Acta 2003, 351, 133-140. [CrossRef]

47. Kornilovich, B.Y.; Pshinko, G.N.; Bogolepov, A.A. Effects of EDTA and NTA on sorption of U(VI) on the clay fraction of soil. Radiochemistry 2006, 48, 584-588. [CrossRef]

48. Pagnanelli, F.; Viggi, C.C.; Mainelli, S.; Toro, L. Assesment of solid reactive mixtures for the development of biological permeable reactive barriers. J. Hazard. Mater. 2009, 170, 998-1005. [CrossRef] [PubMed]

49. Postgate, J.R. The Sulfate Reducing Bacteria, 2nd ed.; Cambridge University Press: Cambridge, NY, USA, 1984; 208p, ISBN 0521257913.

50. Liu, A.; Liu, J.; Han, J.; Zhang, W. Evolution of nanoscale zero-valent iron (nZVI) in water: Microscopic and spectroscopic evidence on the formation of nano- and micro-structured iron oxides. J. Hazard. Mater. 2017, 322, 129-135. [CrossRef] [PubMed]

51. Lee, T.R.; Wilkin, R.T. Iron hydroxy carbonate formation in zerovalent iron permeable reactive barriers: Characterization and evaluation of phase stability. J. Contam. Hydrol. 2010, 116, 47-57. [CrossRef] [PubMed]

52. Langmuir, D. Aqueous Environmental Geochemistry; Prentice Hall: Upper Saddle River, NJ, USA, 1997; 600p, ISBN 0023674121.

53. Kornilovich, B.Y.; Pshinko, G.N.; Koval'chuk, I.A. Effect of Fulvic Acids on Sorption of U(VI) on Clay Minerals of Soils. Radiochemistry 2001, 43, 528-531. [CrossRef] 
54. Kamolpornwijit, W.; Liang, L.; West, O.R.; Moline, G.R.; Sullivan, A.B. Preferential flow path development and its influence on long-term PRB performance: Column study. J. Contam. Hydrol. 2003, 66, 161-178. [CrossRef]

55. Ilankoon, I.M.S.K.; Neethling, S.J. Liquid spread mechanisms in packed beds and heaps. The separation of length and time scales due to particle porosity. Miner. Eng. 2016, 86, 130-139. [CrossRef] 